Klinichna khirurhiia. 2018 August;85(8):58-61.

DOI: $10.26779 / 2522-1396.2018 .08 .58$

\title{
Нові аспекти застосування глісонового методу мобілізаціі воріт печінки в хірургічному лікуванні метастатичного колоректального раку
}

О. О. Колеснік, А. А. Бурлака

Національний інститут раку, м. Київ

\section{New aspects of application of Glissonian method of the hepatic port mobilization in surgical treatment of metastatic colorectal cancer}

\author{
O. O. Kolesnik, A. A. Burlaka
}

National Cancer Institute, Kyiv

Реферат

Мета. Покращити безпосередні результати хірургічного лікування хворих із метастатичним колоректальним раком (МКРР) шляхом удосконалення Глісонового методу резекції печінки.

Матеріали і методи. Проведено ретроспективний аналіз (із січня 2014 по листопад 2017 р.) клінічних даних 62 хворих із МКРР, яким виконували мобілізацію воріт печінки Глісоновим методом.

Результати. Інтраопераційна крововтрата становила ( $382 \pm 221)$ мл, тривалість резекції - $(254 \pm 63,7)$ хв, періопераційна гемотрансфузія - $(380 \pm 120)$ мл, теплова ішемія (селективний маневр Прінгла - СМП) - $(25,1 \pm 13,6)$ хв. Хірургічні ускладнення III і більше ступеня за класифікацією Clavien-Dindo зареестровані у 5 (8,06\%) хворих. Померлих не було. Висновки. Оптимізація Глісонового методу мобілізації воріт печінки продемонструвала його доцільність та ефективність у хірургічному лікуванні МКРР. Основною перевагою цього методу вважаємо можливість визначення варіантної анатомії печінки, зменшення тривалості та об’єму теплової ішемії паренхіми.

Ключові слова: Глісоновий метод; мобілізація воріт печінки; колоректальний рак; метахронне метастатичне ураження печінки.

Abstract

Objective. To improve the immediate results of surgical treatment of patients, suffering metastatic colorectal cancer (MCRC), using improvement of Glissonian method of hepatic resection.

Materials and methods. There was conducted a retrospective analysis (from Jan. 2014 till Nov. 2017 yr.) of clinical data about 62 patients, suffering MCRC, to whom a hepatic port mobilization was performed, using Glissonian method.

Results. Intraoperative blood loss have constituted $(382 \pm 221) \mathrm{ml}$, duration of the resection performance $-(254 \pm 63.7) \mathrm{min}$ perioperative hemotransfusion - $(380 \pm 120) \mathrm{ml}$, and the warm ischemia (selective maneuver of Pringle) $-(25.1 \pm 13.6) \mathrm{min}$. Surgical complications of a Degree III and more in accordance to Clavien-Dindo classification were registered in 5 (8.06\%) patients. Mortality was absent.

Conclusion. Optimization of Glissonian method of the hepatic port mobilization have had demonstrated its expediency and efficacy in surgical treatment of MCRC. Possibility of the variant hepatic anatomy determination, reduction of duration and volume of the warm parenchimatous ischemia are considered the main advantages of this method.

Keywords: Glissonian method; hepatic port mobilization; colorectal cancer; metachronous metastatic hepatic affection.

Щорічно у світі ВООЗ реєструє понад 940 тисяч нових хворих із колоректальним раком (КРР), з яких близько 500 тисяч помирає [1]. За даними Національного канцер-реєстру України КРР займає 3-те місце у структурі смертності від злоякісних новоутворень [2]. Найчастіше органами-мішенями при МКРР є печінка і легені [3]. Резекція печінки з приводу іiі ураження МКРР є беззаперечним стандартом в останні три десятиліття, оскільки забезпечує статистично достовірне покращення віддалених результатів лікування даної когорти хворих [3].

Дисекцію структур гепатодуоденальної зв'язки (ворітної печінкової вени, печінкової артерії, жовчних проток) застосовують при стандартних гемігепатектоміях. Після скелетизації вказаних структур стає можливою позапечінкова транссекція іпсілатеральної гілки ворітної печінко- вої вени та печінкової артерії з метою створення зон демаркації та визначення анатомічних орієнтирів транссекції паренхіми печінки. В окремих спостереженнях (анатомічно складна локалізація метастазу) доцільніше застосувати перетискання портальної тріади в межах гепатодуоденальної зв'язки - маневр Прінгла (МП), що приводить до зменшення крововтрати під час виконання транссекції паренхіми печінки [4].

Проте класичний МП має обмеження через ефект тотальної теплової ішемії печінки та ішемії/реперфузії, що продемонструвала негативний онкологічний ефект in vivo та in vitro [5]. 3 метою уникнення технічно складної дисекції воріт печінки та зменшення крововтрати, тривалості оперативного втручання було застосовано Глісоновий підхід [6, 7]. 
Мета дослідження: покращити безпосередні результати хірургічного лікування хворих із МКРР шляхом впровадження удосконаленого Глісонового методу резекції печінки.

\section{Матеріали і методи дослідження}

Проведено ретроспективний аналіз (із січня 2014 по листопад 2017 р.) впливу методу мобілізації воріт печінки на безпосередні результати лікування хворих із МКРР на базі відділення органів черевної порожнини Національного інституту раку. До дослідження включено 62 хворих із МКРР та метахронним метастатичним ураженням печінки, яким виконували резекцію удосконаленим Глісоновим методом (див.рисунок).

У кожному клінічному спостереженні застосовували мультидисциплінарний розбір, у якому брали участь хірурги, онкологи, хіміотерапевти та радіологи. Діагноз метастатичного ураження печінки підтверджено цитологічним та патогістологічним дослідженням матеріалу, отриманого в результаті тонкоголкової біопсії патологічних вогнищ печінки. Крім того, застосовували комп'ютерну томографію (КТ) грудної, черевної порожнин та малого таза із внутрішньовенним контрастуванням, магнітнорезонансну томографію із внутрішньовенним контрастуванням, а також позитронно-емісійну томографію у разі планування складних резекцій та у хворих з підозрою на наявність метастатичного ураження інших органів.

Хірургічна техніка полягала у виконанні радикальної резекції з максимально можливим збереженням паренхіми та забезпеченням адекватного відступу від краю пухлини (4 - 10 мм). Кожна операція супроводжувалась інтраопераційним ультразвуковим дослідженням (УЗД) з метою розмітки вогнищ по відношенню до магістральних печінкових вен та структур «Глісонового дерева», а також можливого виявлення нових дрібних метастазів. «Великими» резекціями печінки вважали видалення ії трьох та більше сегментів (класифікація C. Couinaud). Техніка ішемії передбачала використання СМП (частка/секція/сегмент). Також застосовували позапечінковий та внутрішньопечінковий Глісоновий метод мобілізації воріт печінки [5]. Транссекцію паренхіми виконували за допомогою методу "crash clamp". Якщо операція була технічно складною, застосовували ультразвуковий кавітатор-аспіратор Söring Ultrasonic Generator Sonoca 300. Гемостазу резектованої паренхіми досягали за допомогою біполярного пінцета, кліпування LT 200, LT 300 та прошивання ниткою пролен товщиною 4-0, 5-0.

Пацієнти отримували хіміотерапію згідно із затвердженими міжнародними та вітчизняними стандартами, ад'ювантну поліхіміотерапію (ПХT) за схемами FOLFOX-6/ FOLFIRI/XELOX (4 - 6 курсів). У разі прогресування захворювання на фоні ПХТ резекцію печінки пацієнтам не виконували. Функціональні резерви печінки оцінювали за шкалами Чайлда-Туркота-П'ю та MELD (Model for End Stage Liver Disease). Прояви токсичності хіміотерапії реєстрували згідно з критеріями СТСАЕ 5.0. Ступені тяжкості гострої печінкової недостатності (ГПН) у післяопераційному періоді оцінювали за класифікацією ISGLS (International Study Group of Liver Surgery).

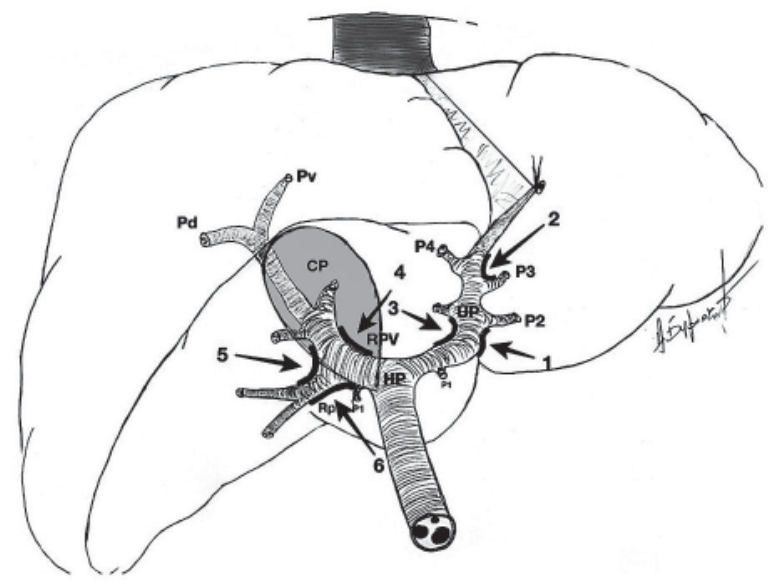

Анатомічні орієнтири та рекомендовані "ворота" (вказані стрілками та дужками)

для мобілізацї основних структур «лісонового дерева» у воротах печінки:

1 - каудальна частина Араниієвої зв'язки;

2 - перехід круглої зв'язки в умбілікальне плато;

3 - правий край ніжки «гісонового дерева» умбілікальной пориї̈ печінки (P2, P3, P4);

4 - лівий край заднъої частини плато жовчного міхура; 5 - біфуркація правої загальної ніжки «лісонового дерева»; 6 простір між ніжкою «лісонового дерева» до заднъої секиї та Р1.

Статистичний аналіз даних проводили з використанням пакета Statistica 8.0. Нормальність розподілу змінних перевіряли тестом Шапіро-Вілка. Перевіряючи статистичні гіпотези, критичним рівнем значущості вважали $\mathrm{p}=0,05$.

\section{Результати}

Серед 62 пацієнтів, включених у дослідження, чоловіків було 34 (54,8\%), жінок - 28 (45,2\%). Вік пацієнтів коливався від 34 до 76 років, середній вік становив $(55 \pm 0,43)$ року. У 39 (62,9\%) пацієнтів первинні пухлини інфільтрували субсерозну оболонку стінки кишечника без інвазії в суміжні органи чи структури (Т3). Ураження регіонарних лімфатичних вузлів рN1 та pN2 зареєстровано у 24 (38,7\%) та 6 (9,5\%) пацієнтів відповідно.

У 25 (40,3\%) хворих виконали «великі» резекції, зокрема, правобічну гемігепатектомію - у 6 (9,6\%), лівобічну у 3 (4,8\%), інші трисегментектомії - у 16 (25,8\%); анатомічну резекцію лівої латеральної секції печінки (сегменти II, III) - у 12 (19,4\%), передньої (сегменти V, VII) - у 1 (1,6\%) та задньої (сегменти VI, VII) - у 6 (9,6\%), інші бісегментектомії - у 6 (9,6\%), анатомічну резекцію одного сегмента - у 6 (9,6\%), атипову резекцію (4 та більше або менше метастазів) - у 6 (9,6\%).

Позапечінковий спосіб виконання Глісонової мобілізації воріт печінки застосовували у 54 (87,1\%) хворих, внутрішньопечінковий - у 8 (12,9\%). Інтраопераційна крововтрата склала (382 \pm 221$)$ мл, тривалість резекції$(254 \pm 63,7)$ хв, теплової ішемії (СМП) - $(25,1 \pm 13,6)$ хв,

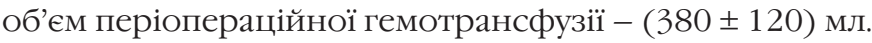
Вважаємо такі результати задовільними та порівнянними зі світовим досвідом. Зокрема, А. Karamarkovic та співавтори повідомили,що, застосовуючи Глісоновий метод, вони знизили кровотрату до $(245,59 \pm 169,39)$ мл, трива- 


\begin{tabular}{|c|c|c|}
\hline \multicolumn{3}{|c|}{ Ускладнення у оперованих хворих } \\
\hline \multirow{2}{*}{ Ускладнення } & \multicolumn{2}{|c|}{ Кількість хворих } \\
\hline & абс. & $\%$ \\
\hline Ексудативний плеврит & 4 & 6,4 \\
\hline Інфекція післяопераційної рани & 2 & 3,2 \\
\hline \multicolumn{3}{|l|}{ ГПН } \\
\hline ступінь А & 2 & 3,2 \\
\hline ступінь В & 1 & 1,6 \\
\hline Білома & 2 & 3,2 \\
\hline Пневмонія & 3 & 4,8 \\
\hline Інші & 1 & 1,6 \\
\hline Всього ... & 15 & 24,2 \\
\hline
\end{tabular}

лість розсічення паренхіми та оперативного втручання - до $(191,18 \pm 41,10)$ хв, об'єм періопераційної трансфузії під час виконання «великих» резекцій печінки - до $(322,86 \pm 102,07)$ мл $(\mathrm{p}<0,05)[6]$.

Оцінюючи перебіг раннього післяопераційного періоду (впродовж перших 30 діб з моменту оперативного лікування), до уваги брали ускладнення та інші клініко-патологічні дані, які могли вплинути на перебіг чи характеризувати його та допомогали судити про переваги і недоліки досліджуваної хірургічної тактики, зокрема, об’єм інтраопераційної крововтрати, тривалість оперативного втручання, кількість ліжко-днів, загальна кількість післяопераційних ускладнень та післяопераційна смертність.

Хірургічні ускладнення III та більше ступеня згідно 3 класифікацією Clavien-Dindo зареєстровані у 5 (8,06\%) хворих. Загалом ускладнення виникли у 15 (24,2\%) хворих (див. таблищю). Середня тривалість перебування хворих у стаціонарі становила $(12,5 \pm 6,1)$ ліжко-дня. Померлих не було.

\section{Обговорення}

Виходячи з анатомічних особливостей розгалуження ніжок «Глісонового дерева», печінку можна умовно розділити на три секції - ліву, серединну та праву, що уможливлює високоселективно контролювати останні у більшості спостережень без застосування інтраопераційного УЗД чи холангіографічної навігації [1]. Асистенція і УЗД частіше $€$ необхідними для розмітки судинних структур у товщі правого венозного ядра. Більше того, УЗД часто забезпечує уникнення великої крововтрати під час транссекції шляхом визначення варіантної артеріальної та венозної анатомії.

Позапечінковий Глісоновий метод передбачає виконання дисекції ворітного плато печінки. Виділити та лігувати загальну праву чи ліву ніжку «Глісонового дерева» необхідно до початку транссекції паренхіми печінки.

Важливо, що, на відміну від класичного МП, селективним перетисканням портальної тріади Глісоновим методом уникали системного патологічного ефекту ішемії/реперфузії в майбутній культі печінки і тим самим попереджали можливі негативні онкологічні наслідки для оперованого хворого (неконтрольоване пухлинне прогресування) [8].

Глісоновий метод мобілізації воріт печінки здобув популярність за останнє десятиліття завдяки відносній про- стоті. Перші публікації, присвячені порівнянню Глісового методу з стандартним методом дисекції структур гепатодуоденальної зв'язки, показали його ефективність та доцільність. Зокрема, T. Nakai і співавтори, які виконали 90 гепатектомій, у групі хворих, оперованих Глісоновим методом, спостерігали зменшення інтраопераційної крововтрати, тривалості оперативного втручання та частоти післяопераційних ускладнень у порівнянні із стандартним методом дисекції воріт печінки та селективного лігування [9]. Інші дослідники стверджують, що безпосередні та віддалені результати Глісонового і селективного методів порівнянні [10]. У проспективному рандомізованому дослідженні J. Figueras і співавтори порівняли Глісоновий метод із дисекцією воріт печінки при їі великих резекціях та встановили, що транссекція воріт печінки у блоці 3 ніжкою «Глісонового дерева» була достовірно швидшою, ніж селективна [5]. Обидві техніки не мали відмінностей за безпосередніми та віддаленими результатами, проте було зареєстровано менш виражене ішемічне пошкодження паренхіми печінки у разі застосування Глісонового методу, особливо у хворих із цирозом печінки [3]. Таким чином, мінімальна ішемізація всієї печінки та/чи частки/ секції в результаті застосування Глісонового методу сприяє покращенню якості хірургічного лікування хворих із МКРР. У подальших дослідженнях продемонстровано переваги Глісонового методу мобілізації воріт печінки у порівнянні із застосуванням класичного МП при резекції печінки у хворих із гепатоцелюлярним раком (понад 5 см). Загальна 5-річна виживаність становила відповідно 36,4 та 64,7\% (р < 0,0001) [11]. Крім того, у пацієнтів, оперованих Глісоновим методом реєстрували меншу частоту рецидиву захворювання ( $=0,0013)$.

Про дієвість Глісонового підходу також повідомили М. Yamamoto та співавтори, які застосували його у хворих із гепатоцелюлярною карциномою (ГЦК). Відмічено достовірне покращення віддалених результатів, 5-річна загальна виживаність становила 21 та 67\% відповідно у хворих контрольної групи та у хворих, оперованих Глісоновим методом ( $<$ <,001) [12]. Покращену виживаність автори пояснили тим, що ГЦК має тенденцію до інфільтрації центральних судинних структур, тоді як застосування принципів Глісонового підходу попереджає поширення пухлини $з$ плином крові.

За останнє десятиліття тенденції хірургічного лікування захворювань печінки змінилися на користь застосування паренхімозберігаючого підходу, особливо у хворих із МКРР, який передбачає видалення зони печінки, ураженої пухлиною/метастазом, з максимальним збереженням здорової паренхіми. Перевагою такої хірургічної тактики вважають кращу якість життя хворого за рахунок зниження частоти гострої та хронічної печінкової недостатності у результаті збереження фукціонуючої паренхіми, а також можливість виконання повторної резекції за потреби. Внутрішньопечінковий Глісоновий метод дає змогу виконувати паренхімозберігаючу резекцію, оскільки уможливлює доступ до ніжок «Глісонового дерева» другого та навіть третього порядку через невеликі доступи з урахуванням анатомічних орієнтирів. Цей метод також показаний, коли пухлина локалізується в межах од- 
ного анатомічного сегмента. Вважають, що у разі високоселективного інтрапаренхіматозного лігування судин, які забезпечують функціонування зони росту пухлини/метастазу, можна виконати більш щадну резекцію печінки із максимальним збереженням їі майбутньої культі. Це підтверджено у ряді наукових публікацій щодо застосування Глісонового методу для резекції одного із анатомічних сегментів печінки [13]. У окремих хворих дисекція зон біфуркації ніжки «Глісонового дерева» може бути технічно утрудненою, що особливо стосується повторної резекції. Саме таким хворим слід застосовувати внутрішньопечінковий Глісоновий метод. Лівобічну гемігепатектомію чи резекцію лівої латеральної секції було виконано 360 хворим. Зменшення тривалості оперативного втручання на $(77 \pm 35)$ хв та крововтрати на $(110 \pm 25)$ мл зафіксовано у хворих, яких оперували із застосуванням внутрішньопечінкового Глісонового методу мобілізації воріт печінки. Крім того, автори не зареєстрували післяопераційної летальності [14]. Внутрішньопечінковий Глісоновий метод успішно застосовували при резекції центральних сегментів печінки (IV, V та VIII), передньої (сегменти V та VIII) та задньої (сегменти VI та VII) секцій [15].

\section{Висновки}

1.Оптимізація Глісонового методу продемонструвала його доцільність та ефективність щодо резекції печінки у хворих із МКРР.

2. Основною перевагою Глісонового підходу вважаємо можливість визначення варіантної анатомії печінки, зменшення тривалості резекції, об'єму крововтрати та теплової ішемії паренхіми органа.

\section{References}

1. Bignell M, Chave H, Branagan G, et al. Outcome of surgery for recurrent anal cancer - results from a tertiary referral centre. Colorectal Dis. 2018 Mar 24. doi: 10.1111/codi.14098.

2. Fedorenko Z, Michailovich Y, Goulak L, et al. Bulletin of National Cancer Registry of Ukraine № 18, 2015-2016.

3. Tohme S, Kameneva MV, Yazdani HO, Sud V, Goswami J, Loughran P, et al. Drag reducing polymers decrease hepatic injury and metastases after liver ischemia-reperfusion. Oncotarget. 2017 May 31;8(35):5985459866. doi: 10.18632/oncotarget.18322.

4. Takasaki K, Kobayashi S, Tanaka S, Saito A, YamamotoM, Hanyu F. Highly anatomically systematized hepatic resection with Glissonean sheath code transection at the hepatic hilus. International Surgery. 1990;75(2):73-7. PMID: 2166006.

5. Figueras J, Lopez-Ben S, Llado L, Rafecas A, Torras J, Ramos E, et al. Hilar dissection versus the Bglissonean approach and stapling of the pedicle for major hepatectomies: a prospective, randomized trial. Annals of Surgery. 2003 Jul;238(1):111-9. doi: 10.1097/01. SLA.0000074981.02000.69.

6. Karamarković A, Doklestić K, Milić N, Djukić V, Bumbasirević V, Sijački A, et al. Glissonean pedicle approach in major liver resections. Hepatogastroenterology. 2012 Sep;59(118):1896-901. doi: 10.5754/hge12198.

7. Lim C, Broqueres-You D, Brouland JP, et al. Hepatic ischemia-reperfusion increases circulating bone marrow-derived progenitor cells and tumor growth in a mouse model of colorectal liver metastases. J Surg Res. 2013 Oct;184(2):888-97. doi: 10.1016/j.jss.2013.04.069. Epub 2013 May 21.

8. Chinburen J, Gillet M, Yamamoto M, Enkh-Amgalan T, Taivanbaatar E, Enkhbold C, et al. Impact of Glissonean pedicle approach for centrally located hepatocellular carcinoma in mongolia. International Surgery. 2015 Feb;100(2):268-74. doi: 10.9738/INTSURG-D-14-00006.1

9. Nakai T, Koh K, Funai S, Kawabe T, Okuno K, Yasutomi M. Comparison of controlled and Glisson's pedicle transections of hepatic hilum occlusion for hepatic resection. Journal of the American College of Surgeons. 1999 Sept;189(3):300-4. PMID: 10472931.

10. Tsuruta K, Okamoto A, Toi M, Saji H, Takahashi T. Impact of selective Glisson transection on survival of hepatocellular carcinoma. Hepatogastroenterology. 2002 Nov-Dec;49(48):1607-10. PMID: 12397746.

11. 11. Ji B, Wang Y, Wang G, et al. Curative resection of hepatocellular carcinoma using modified Glissonean pedicle transection versus the Pringle maneuver: a case control study. Int J Med Sci. 2012;9(10):843-52. doi: 10.7150/ijms.4870. Epub 2012 Nov 1.

12. Yamamoto M, Takasaki K, Ohtsubo T, Katsuragawa H, Fukuda C, Katagiri S. Effectiveness of systematized hepatectomy with Glisson's pedicle transection at the hepatic hilus for small nodular hepatocellular carcinoma: retrospective analysis. Surgery. 2001;130(3):443-8. doi: 10.1067/msy.2001.116406.

13. Figueroa R, Laurenzi A, Laurent A, Cherqui D. Perihilar Glissonian Approach for Anatomical Parenchymal Sparing Liver Resections: Technical Aspects: The Taping Game. Ann Surg. 2018 Mar;267(3):537-543. doi: 10.1097/SLA.0000000000002100.

14. Moris D, Rahnemai-Azar AA, Tsilimigras DI, Ntanasis-Stathopoulos I, Marques HP, Spartalis E, et al. Updates and Critical Insights on Glissonian Approach in Liver Surgery. J Gastrointest Surg. 2018 Jan;22(1):154163. doi: 10.1007/s11605-017-3613-9. Epub 2017 Nov 3.

15. Cho A, Yamamoto H, Kainuma O, Ota T, Park S, Yanagibashi H. Arantius' ligament approach for the left extrahepatic Glissonean pedicle in pure laparoscopic left hemihepatectomy. Asian J Endosc Surg. 2012 Nov;5(4):187-90. doi: 10.1111/j.1758-5910.2012.00139.x. 